\title{
TINGKAT KEBANGKRUTAN DAN KARAKTERISTIK PERUSAHAAN TERHADAP NILAI PERUSAHAAN (SEBUAH MODEL : PENDEKATAN SPRINGATE)
}

\author{
Tri Astuti
}

Fakultas Ekonomi dan Bisnis, Universitas Pancasila

Email:triastuti@univpancasila.ac.id

Diterima 30 Agustus 2018, Disetujui 24 September 2018

\begin{abstract}
Abstrak
Penelitian ini bertujuan untuk menguji pengaruh Z-Score, Size Firm, Leverage Ratio, Sales Growth terhadap Nilai Perusahaan yang diproksikan sebagai PBV,studi pada Perusahaan Telekomunikasi yang terdaftar dalam Bursa Efek Indonesia. Data yang digunakan dalam penelitian ini diperoleh dari Laporan Keuangan Publikasi Perusahaaan Sektor Telekomunikasi periode 2010- 2016. Model analisis data yang digunakan adalah regresi linier berganda dengan persamaan kuadrat terkecil. Hasil penelitian ini menunjukkan bahwa Z'Score tidak berpengaruh signifikan terhadap PBV, Variabel Size berpengaruh positif signifikan terhadap PBV, Leverage berpengaruh positif terhadap PBV dan Growth tidak berpengaruh signifikan terhadap PBV. Variable Z-Score (Z), Size Firm (Size), Leverage Ratio (Leverage), Sales Growth (Growth) secara bersama simultan berpengaruh terhadap variable dependen Nilai Perusahaan (PBV). Uji determinasi atau variasi model dari keempat variabel tersebut terhadap PBV dalam penelitian ini sebesar 90,2\% sedangkan sisanya 9,8\% dipengaruhi oleh variabel lain yang tidak dimasukkan kedalam model perusahaan.
\end{abstract}

Kata Kunci : Z-Score, Ukuran Perusahaan, Leverage, Pertumbuhan Penjualan, Harga Nilai Buku

\section{Abstract}

This study aims to examine the effect of Z-Score, Size Firm, Leverage Ratio, Sales Growth on the Value of the Company proxied as $P B V$, studies in Telecommunications Companies listed in the Indonesia Stock Exchange. The data used in this study was obtained from the Telecommunication Sector Publication Financial Report for the period 2010-2016. The data analysis model used was multiple linear regression with the least squares equation. The results of this study indicate that Z'Score has no significant effect on $P B V$, Variable Size has a significant positive effect on PBV, Leverage has a positive effect on PBV and Growth has no significant effect on PBV. Variable Z-Score (Z), Size Firm (Size), Leverage Ratio (Leverage), Sales Growth (Growth) simultaneously simultaneously affect the dependent variable Corporate Value (PBV). Test of determination or variation of the models of the four variables on PBV in this study amounted to $90.2 \%$ while the remaining $9.8 \%$ was influenced by other variables not included in the company model.

Keywords: Z-Score, Size Firm, Leverage, Sales Growth, Price Book Value 


\section{PENDAHULUAN}

\section{Latar Belakang Penelitian}

Prinsip semua pelaku usaha adalah mencari laba dan berusaha untuk meningkatkan labanya secara terus menerus. Laba yang diperoleh, sangat ditentukan oleh kinerja perusahaan itu sendiri yang dilakukan dengan efektifitas dan efesiensi. Perusahaan yang mempunyai tujuan jangka pendek yaitu memperoleh keuntungan dan secara jangka panjang harus bisa mempertahankan dan memaksimalkan nilai perusahaan. Nilai perusahaan tercermin dari harga sahamnya yang diproksikan dengan Price Book Value (PBV), dimana semakin tinggi harga saham dari perusahaan maka semakin tinggi nilai perusahaan yang diperoleh. Nilai perusahaan sangat penting karena dapat mempengaruhi pengambilan keputusan investor terhadap perusahaan. Seorang investor yang membeli saham suatu perusahaan berarti perusahaan tersebut diharapkan akan memberi prospek atau harapan untuk investor tersebut Prospek perusahaan membaik atau bagus maka harga saham (nilai perusahaan) akan meningkat. Untuk mengetahui prospek kondisi finansial suatu perusahaan dengan cara menganalisis Rasio Likuiditas, Rasio Solvabilitas, Rasio Profitabilitas, dan Rasio Aktivitas, sehingga dapat diketahui hasil-hasil yang telah dicapai. Perusahaan yang tidak mampu mempertahankan kinerja, lambat laun dapat tergusur dari industri dan akan mengalami kebangkrutan atau kesulitan keuangan (financial distress). Financial distress apabila tidak segera diatasi maka berdampak besar terhadap investor atau hilangnya kepercayaan dari investor dalam hal penananam investasinya.

Kinerja keuangan akan menentukan tinggi rendahnya harga saham di pasar modal dan fluktuasi harga saham akan dipengaruhi oleh kinerja keuangan perusahaan. Kinerja keuangan perusahaan yang menunjukkan adanya prospek yang baik, maka sahamnya akan diminati investor dan harganya meningkat. Dan sebaliknya bila kinerja keuangan tidak menunjukkan prospek yang baik kemungkinan diprediksi menuju kebangkrutan. Untuk mendeteksi kemungkinan perusahaan tinggi untuk bangkrut atau mengalami bangkrut rendah dengan menggunakan Model Springate.

Karakteristik merupakan sesuatu spesifik yang dimiliki oleh perusahaan yang dapat dikembangkan oleh perusahaan untuk kepentingannya. Faktorfaktor komponen karakteristik yang dapat meningkatkan nilai perusahaan (harga saham) diantaranya adalah size firm, leverage, dan growth.
Firm Size adalah besarnya perusahaan. Semakin besar perusahaan maka semakin besar aktivanya maka semakin banyak modal yang ditanam, dan semakin besar kapitalisasi pasar maka besar pula kemungkinan dikenal publik. Leverage mengukur besarnya aktiva perusahaan yang dibiayai oleh hutang dengan membandingkan total hutang terhadap keseluruhan asset suatu perusahaan. Semakin besar Leverage suatu perusahaan, akan menurunkan nilai perusahaan disebabkan besarnya hutang yang tinggi melebihi besarnya aktiva perusahaan, dan sebaliknya leverage yang rendah akan meningkatkan nilai perusahaan. Growth (Pertumbuhan) menurut Fahmi (2014:82) adalah sebagai berikut : Rasio pertumbuhan yaitu rasio yang mengukur seberapa besar kemampuan perusahaan dalam mempertahankan posisinya didalam industri dan dalam perkembangan ekonomi secara umum."Pertumbuhan penjualan tinggi merupakan signal bahwa perusahaan mempunyai prospek bisnis yang baik, pertumbuhan memberi harapan bahwa rate of return dari investasi yang ditanamkan akan meningkat.

\section{TujuanPenelitian}

Berdasarkan perumusan masalah diatas, maka tujuan dari penelitian ini adalah: 1) Untuk mengetahui pengaruh parsial antara Model Springate terhadap Nilai Perusahaan; 2) Untuk mengetahui pengaruh parsial antara Size Firm terhadap Nilai Perusahaan; 3) Untuk mengetahui pengaruh parsial antara Leverage terhadap Nilai Perusahaan; 4) Untuk mengetahui pengaruh parsial antara Growth terhadap Nilai Perusahaan; 5) Untuk mengetahui pengaruh simultan antara Model Springate, Size Firm,Leverage,Growth terhadap Nilai Perusahaan.

\section{KAJIAN TEORI}

\section{Nilai Perusahaan}

Nilai perusahaan adalah persepsi investor terhadap tingkat keberhasilan perusahaan yang dikaitkan dengan harga saham. Harga saham yang tinggi akan memberikan keuntungan, yaitu berupa capital gain dan citra yang lebih baik bagi perusahaan sehingga memudahkan bagi manajemen untuk mendapatkan dana dari luar perusahaan yang membuat nilai perusahaan juga tinggi, dan meningkatkan kepercayaan pasar tidak hanya terhadap kinerja perusahaan saat ini namun juga pada prospek dimasa mendatang.

Semakin tinggi harga saham, semakin berhasil perusahaan menciptakan nilai perusahaan. Nilai 
perusahaan dapat diukur dengan rasio harga saham terhadap nilai buku perusahaan.Umumnya rasio ini

\section{Model Springate}

Prediksi kebangkrutan dengan menggunakan 4 rasio keuangan yaitu dengan rumus: mencapai diatas satu, yang ditunjukkan bahwa nilai pasar saham lebih besar dari nilai bukunya.
$\mathrm{Z}=1,03 \mathrm{~A}+3,07 \mathrm{~B}+0,66 \mathrm{C}+0,4 \mathrm{D}$

Keterangan:

A = Working Capital to Total Asset

Working Capital to Total Assets $=$ Total Aktiva Lancar-Total Hutang Lancar $\quad x 100 \%$ Total Aktiva

$\mathrm{B}=$ Net Profit Before Interest and Taxes to Total Assets

Net Profit Before Taxes to Current Liabilities $=\frac{E B T}{\text { Total Currt Liabilties }} \quad x 100 \%$

Total Current Liabilties

$\mathrm{C}=$ Net Profit before Taxes to Current Liabilities

Net Profit Before Interest and Taxes to Total Assets $=\quad$ EBIT $\quad$ x $100 \%$

Total Aktiva

$\mathrm{D}=$ Sales to Total Asset

Sales to Total Asset $=\quad$ Sales $\times 100 \%$

Total Asset

Jika Skor $\mathrm{Z}<0.862$ merupakan perusahaan yang bangkrut dan Skor Z > 0.862 merupakan perusahaan yang tidak berpotensi bangkrut.

\section{Karakteristik Perusahaan}

1) Firm Size, Ukuran perusahaan dianggap mampu mempengaruhi nilai perusahaan. Ukuran perusahaan dapat dilihat dari total aset yang dimiliki oleh suatu perusahaan. Ukuran perusahaan yang besar mencerminkan bahwa perusahaan tersebut sedang mengalami perkembangan dan pertumbuhan yang baik sehingga meningkatkan nilai dari suatu perusahaan. Nilai perusahaan yang meningkat dapat ditandai dengan total aktiva perusahaan yang mengalami kenaikan dan lebih besar dibandingkan dengan jumlah hutang perusahaan; 2) Leverage, merupakan kebijakan pendanaan yang berkaitan dengan keputusan perusahaan dalam membiayai perusahaan. Penggunaan hutang (ekternal financing) memiliki resiko yang cukup besar atas tidak terbayarnya hutang, sehingga penggunaan hutang perlu memperhatikan kemampuan perusahaan dalam menghasilkan laba (Prasetyorini, 2013); 3) Sales Growth (Perumbuhan) menurut Fahmi (2014 :82) adalah: "Rasio pertumbuhan yaitu rasio yang mengukur seberapa besar kemampuan perusahaan dalam mempertahankan posisinya didalam industri dan dalam perkembangan ekonomi secara umum. Rasio pertumbuhan dapat dilihat dari berbagai segi yaitu sales (penjualan), earning after tax (EAT), laba per lembar saham, deviden per lembar saham, dan harga pasar per lembar saham.

\section{Penelitian Terdahulu}

Berbagai penelitian yang telah dilakukan oleh peneliti sebelumnya meliputi: 1) Penelitian oleh Ninik Mardiana Tanjung (2011) dengan judul Analisis Potensi Kebangkrutan dan Hubungannya dengan Return Saham Pada Perusahaan Perbankan Yang Terdaftar Di Bursa Efek Indonesia Periode 20072010, bahwa nilai potensi kebangkrutan berpengaruh terhadap harga saham sebesar 18\% sedangkan 82\% dipengaruhi factor lain, penelitian oleh Andromeda Adrian, dan Moh Khoiruddin (2014) dengan judul Pengaruh Analisis Kebangkrutan Model Altman Terhadap Harga Saham Perusahaan Manufaktur.Secara simultan rasio keuangan pembentuk Z'Score berpengaruh terhadap Harga Saham. Secara parsial, rasio Working Capital to Total Asset dan Sales/Total Asset berpengaruh negatif terhadap Harga Saham, rasio EBIT/TA berpengaruh positif terhadap Harga Saham, rasio RE/TA dan MVE/BVD tidak berpengaruh terhadap harga saham; 2) Penelitian oleh Andyni Yulfanis Aulia Masrifa (2016) dengan judul Pengaruh Karakteristik Perusahaan Terhadap Nilai Perusahaan Dengan 
Devidend Payout Ratio Sebagai Variabel Intervening Perusahaan Manufaktur Yang Terdafar Pada Bursa Efek Indonesia Periode 2006-2010. Bahwa Firm Size pada perusahaan manufaktur periode 2006-2010 berpengaruh positif terhadap Nilai Perusahaan, Sales Growth berpegaruh negatif dan tidak signifikan terhadap nilai perusahaan. ROA berpengaruh positif terhadap PBV; 3) Penelitian oleh Fadly Saputra (2016) dengan judul Analisis Pengaruh Profitabilitas, Keputusan Investasi, Leverage, Ukuran Perusahaan Terhadap Nilai Perusahaan (Studi Pada Perusahaan Manufaktur Yang Terdaftar di Bursa Efek Indonesia 2012-2014), Dapat disimpulkan Profitabilitas (ROA) berpengaruh positif dan signifikan terhadap Nilai Perusahaan, Keputusan Investasi (PER) berpengaruh positif dan signifikan terhadap Nilai Perusahaan, Leverage (DER) tidak berpengaruh negatif dan signifikan terhadap Nilai Perusahaan, Ukuran Perusahaan (Size) tidak berpengaruh positif terhadap Nilai Perusahaan; 4) Penelitian oleh Eva Eko Hidayati (2010) dengan judul Analisis Pengaruh DER, DPR, ROE, Dan Size Terhadap PBV Perusahaan Manufaktur Yang Listing Di BEI Periode 2005-2007, Secara simultan DER, DPR, ROE, Size secara bersama-sama perngaruh terhadap PBV, secara individu, DER, DPR berhubungan negatif dan tidak signifikan dengan PBV, ROE dan Size berhubungan positif signifikan terhadap PBV.

VARIABEL INDEPENDEN

VARIABEL DEPENDEN

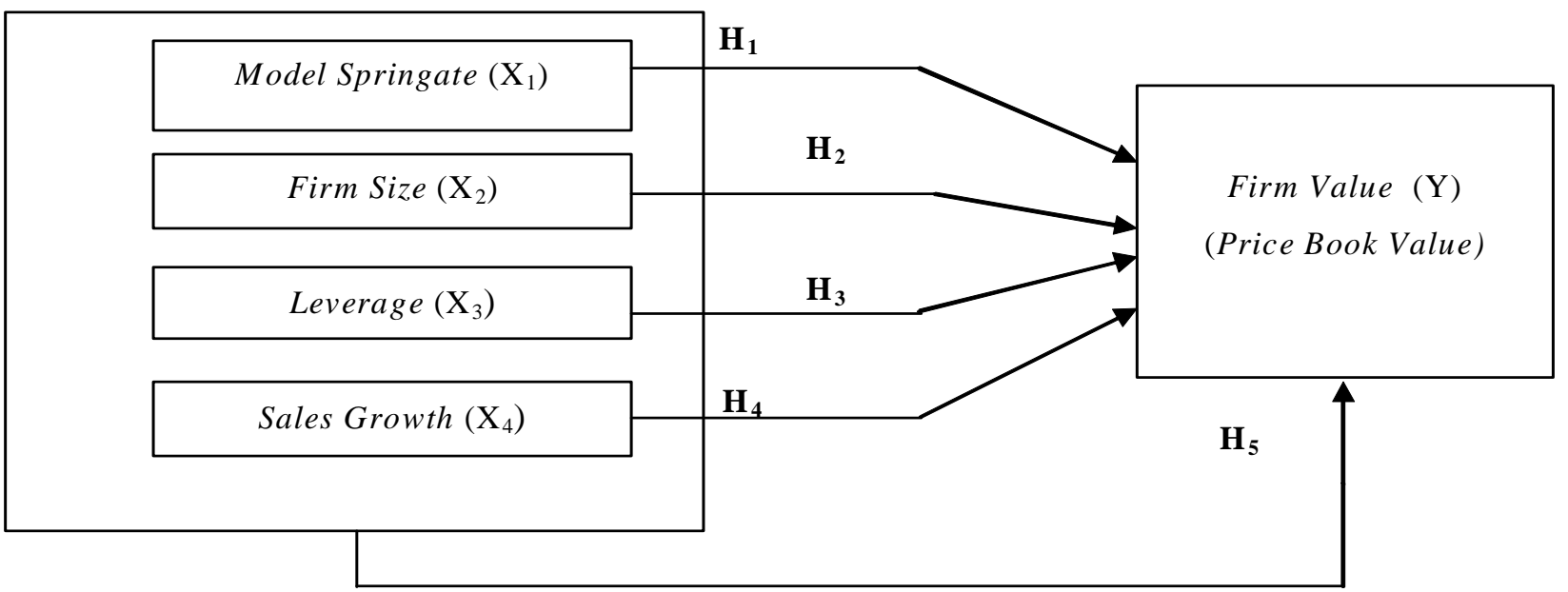

Gambar 1. Kerangka Pemikiran

\section{Hipotesis}

1) Tingkat Kebangkrutan Model Springate, Penelitian dari Effendi, Azhar, Iwan Shidarta (2016), Ailando (2011) menyatakan bahwa Financial Distress berpengaruh positif terhadap nilai perusahaan. Hal ini karena naik turunnya harga saham berhubungan langsung dengan peningkatan dan penurunan nilai perusahaan sehingga mengurangi menambah kemakmuran pemilik saham. Berbeda dengan Steven dkk (2011) menemukan Financial Distress berpengaruh negative signifikan terhadap nilai perusahaan. Hal ini dikarenakan, semakin tinggi tingkat kebangkrutan suatu perusahaan akan mengalami penurunan terhadap nilai perusahaan. $\mathrm{H}_{1}$ : Tingkat Kebangkrutan Model Springate berpengaruh positif signifikan terhadap nilai perusahaan; 2) Ukuran Perusahaan (Size Firm), Penelitian dari Maryam (2014), Prasetyorini (2013), I G Bagus Angga Pratama dan I Gusti Bagus Wiksuana (2016), Gede Rudangga dan Gede Merta Sudiarta (2016),
Andyni Yulfanis Aulia Masrifa (2016) yang menyatakan bahwa ukuran perusahaan berpengaruh positif signifikan terhadap nilai perusahaan. Sedangkan menurut I Nyoman Agus Suwardika dan I Ketut Mustanda (2017), Fadly Saputra (2016) menyatakan bahwa ukuran perusahaan terhadap nilai perusahaan tidak berpengaruh signifikan. $\mathrm{H}_{2}$ : Size Firm berpengaruh positif signifikan terhadap nilai perusahaan; 3) Leverage, Penelitian oleh Hermuningsih (2013) yang menyatakan bahwa leverage berpengaruh positif dan signifikan terhadap nilai perusahaan. Penelitian Uguanyi (2012) menyatakan bahwa peningkatan hutang di struktur modal meningkatkan kekayaan pemegang saham yang nantinya akan berpengaruh terhadap nilai perusahaan. Sedangkan penelitian dari Putu Mikhy Novari dan Putu Vivi Lestari, (2016) menyatakan bahwa leverage tidak berpengaruh signifikan terhadap nilai perusahaan, Fadly Saputra (2016) Leverage (DER) tidak berpengaruh negatif dan 
signifikan terhadap Nilai Perusahaan. Penelitian oleh Eva Eko Hidayati (2010), DER berhubungan negatif dan tidak signifikan dengan PBV. H3: Leverage berpengaruh positif signifikan terhadap nilai perusahaan; 4) Sales Growth, Penelitian yang dilakukan oleh Sriwandany (2006) menemukan bahwa pertumbuhan perusahaan mempunyai pengaruh langsung dan positif terhadap perubahan harga saham, yang artinya bahwa informasi tentang adanya pertumbuhan perusahaan direspon positif oleh investor, sehingga meningkatkan harga saham.Sedangkan menurut I Nyoman Agus Suwardika dan I Ketut Mustanda (2017), bahwa variable partumbuhan perusahaan mempunyai hubungan yang negative terhadap nilai Perusahaan. Dan menurut Verawati Hansen dan Juniarti (2014), serta Andyni Yulfanis Aulia Masrifa (2016) dan menyatakan bahwa sales growth memiliki pengaruh yang negative dan tidak signifikan terhadap nilai perusahaan. H4: Sales Growth berpengaruh positif signifikan terhadap nilai perusahaan; 5) Tingkat Kebangkrutan Model Springate, Size Firm, Leverage, Sales Growth, Penelitian yang dilakukan oleh Raissa Karina Loman dan Mariana Ing Malelak (2015) menyatakan bahwa Model Kebangkrutan Springate, Size Firm, Sales Growth, dan Leverage berpengaruh simultan terhadap Nilai Perusahaan. H5: Tingkat Kebangkrutan Model Springate, Size Firm, Leverage, Sales Growth berpengaruh simultan terhadap Nilai Perusahaan.

\section{METODE}

\section{Desain Penelitian}

Jenis penelitian yang digunakan dalam penelitian ini adalah penelitian kuantitatif, dan penelitian kausal komparatif atau hubungan sebab akibat (Causal Comparatif Research) dengan menggunakan data sekunder.

\section{Populasi dan Sample}

Populasi yang akan menjadi objek penelitian adalah perusahaan telekomunikasi yang terdaftar di Bursa Efek Indonesia (BEI) selama periode 20102016. Teknik penentuan sampel adalah purpose judgement sampling, dimana penelitian tidak dilakukan pada seluruh populasi tetapi terfokus pada target, sampel yang didapat merupakan representasi dari populasi sampel yang ada serta sesuai dengan kepentingan dan tujuan penelitian. Cara pengambilan sampel berdasarkan kriteria tertentu yaitu : 1) Telah menyampaikan laporan keuangan tahun 2010-2016 dan telah diaudit; 2) Laporan keuangan telah diaudit dengan pendapat wajar tanpa pengecualian; 3) Perusahaan menyajikan laporan keuangan dalam mata uang rupiah; 4) Tahun buku berakhir pada tanggal 31 Desember.Untuk sampel dalam penelitian adalah PT Indosat Tbk (ISAT), PT Telekomunikasi Indonesia Tbk (TLKM), PT XL Axiata Tbk (EXCL), PT Bakrie Telecom Tbk (BTEL), PT Smartfren Telecom Tbk (FREN).

\section{Operasional Variabel}

Variabel yang digunakan dalam penelitian ini adalah: 1) Variable Bebas (IndependenVariabel =X) adalah variable yang mempengaruhi, meliputi $\mathrm{X}_{1}=$ Tingkat Kebangkrutan dengan Pendekatan Springate (Z), $\mathrm{X}_{2}=$ Firm Size, $\mathrm{X}_{3}=$ Leverage, $\mathrm{X}_{4}=$ Sales Growth; 2) VariableTerikat/ Tidak Bebas (Dependen Variabel= Y) adalah variable yang dipengaruhi oleh variable bebas, yaitu Nilai Perusahaan (PBV).

Analisa prosedur yang digunakan adalah Analisis Regresi Linier Berganda (Mulitiple Regression) dengan menggunakan metode kuadrat terkecil biasa dengan bantuan Statistical Package for Social Sciences (SPSS) versi 22,0 dengan menggunakan tingkat kepercayaan (convidence interval) sebesar 95\% dan tingkat kesalahan (alpha) 5\%.

\section{Unit Analisis}

\begin{tabular}{|c|c|c|}
\hline Variabel & $\begin{array}{ll}\text { Pengukuran } \\
\end{array}$ & Skala \\
\hline $\begin{array}{c}\text { Price to Book Value } \\
\text { (Y) }\end{array}$ & $\begin{array}{l}\mathrm{PBV}=\text { Market Price per Share } \\
\text { Book Value per Share }\end{array}$ & Rasio \\
\hline \multirow[t]{4}{*}{$\begin{array}{c}\text { Kebangkrutan } \\
\text { (Model Springate) } \\
\text { (X1) }\end{array}$} & $\begin{array}{l}\mathrm{Z}=1,03 \mathrm{~A}+3,07 \mathrm{~B}+0,66 \mathrm{C}+0,4 \mathrm{D} \\
\mathrm{A}=\text { Working Capital to Total Asset }\end{array}$ & Rasio \\
\hline & $=\frac{\text { Total Aktiva Lancar- Total Hutang Lancar }}{\text { Total Aktiva }} \times 100 \%$ & \\
\hline & $\mathrm{B}=$ Net Profit Before Interest and Taxes to Total Assets & \\
\hline & $=\frac{E B T}{\text { Total Current Liabilties }} \quad \times 100 \%$ & \\
\hline
\end{tabular}




\section{Lanjutan Unit Analisis}

\begin{tabular}{|c|c|c|}
\hline Variabel & Pengukuran & Skala \\
\hline \multirow{6}{*}{$\begin{array}{c}\text { Kebangkrutan } \\
\text { (Model Springate) } \\
\text { (X1) }\end{array}$} & & Rasio \\
\hline & $\mathrm{C}=$ Net Profit before Taxes to Current Liabilities & \\
\hline & $=\frac{\mathrm{EBIT}}{\mathrm{T}} \times 100 \%$ & \\
\hline & Total Aktiva & \\
\hline & $\mathrm{D}=$ Sales to Total Asset & \\
\hline & $=\frac{\text { Sales }}{\text { Total Asset }} \quad \times 100 \%$ & \\
\hline Size (X2) & Size $=$ Ln Total Aktiva & Nominal \\
\hline Leverage (X3) & $\frac{\text { Total Hutang }}{\text { Total Equity }} \quad$ x 100\% & Rasio \\
\hline Sales Growth (X4) & Sales Growth $=\frac{(\text { Sales t- Sales t }-1)}{\text { Sales t }_{-1}} \quad \times 100 \%$ & Rasio \\
\hline
\end{tabular}

HASIL DAN PEMBAHASAN

\section{Statistik Deskriptif}

Tabel 1. Hasil Uji Statistic Deskriftif

Descriptive Statistics

\begin{tabular}{lrrrrr}
\hline & N & Minim um & \multicolumn{1}{c}{ Maximum } & \multicolumn{1}{c}{ Mean } & \multicolumn{1}{c}{ Std. Deviation } \\
\hline PBV & 35 & $-17,940$ & 4,230 & 1,21229 & 3,598316 \\
\hline Z'Score & 35 & $-963,657$ & 169,390 & $-35,79217$ & 240,405000 \\
\hline Size & 35 & 25,221 & 32,387 & 29,88574 & 1,811023 \\
\hline Leverage & 35 & $-3852,513$ & 452,656 & 17,84554 & 717,671807 \\
\hline Growth & 35 &,- 776 & 1,535 &, 06560 &, 369300 \\
\hline $\begin{array}{l}\text { Valid N } \\
\text { (listwise) }\end{array}$ & 35 & & & & \\
\hline
\end{tabular}

Sumber : Output SPSS 21 Laporan Keuangan Publikasi, Diolah (2018)

Pada tabel 1 menunjukkan bahwa jumlah data yang digunakan dalam penelitian ini sebanyak 35 sampel data yang diambil dari data observasi yang berasal dari perkalian antara periode penelitian (7 tahun; mulai dari tahun 2010- 2016) dengan jumlah perusahaan sampel (5 perusahaan).

Hasil perhitungan diatas nampak bahwa Variabel Price Value Book (PBV) memiliki nilai terendah (minimum) sebesar -0,17940 yaitu PT Smartfren Telecom Tbk (FREN) pada tahun 2010 dan PBV nilai tertinggi (maksimum) sebesar 0,0423 yaitu PT Telekomunikasi Indonesia Tbk (TLKM) pada tahun 2016 dan nilai rata-rata PBV sebesar 0,01212.Standar deviasi (simpangan baku) untuk PBV adalah 0,03598 diatas dari mean nya sebesar 0,01212. Dengan demikian dapat dikatakan bahwa simpangan data pada rasio PBV relatif baik atau tingkat variasi data dari pertumbuhan penjualan besar atau heterogen.
Rasio Z'Score terendah (minimum) sebesar 9,63657 pada PT Bakrie Telecom Tbk (BTEL) pada tahun 2015 dan yang tertinggi (maksimum) sebesar 1,6939 pada PT Telekomunikasi Indonesia Tbk (TLKM) pada tahun 2012, kemudian rata-rata Z'Score sebesar -0,35792.Sedangkan standar deviasi untuk Z'Score adalah 2,40405 diatas dari mean nya sebesar -0,35792. Dengan demikian dapat dikatakan tingkat variasi data dari rasio Z'Score besar atau heterogen atau data pada Z'Score relatif baik.

Rasio Size terendah (minimum) sebesar 0,25221 yaitu pada PT Bakrie Telecom Tbk (BTEL) pada tahun 2016 dan yang tertinggi (maksimum) sebesar 0,32387 yaitu pada PT Telekomunikasi Indonesia Tbk (TLKM) pada tahun 2016, kemudian rata-rata Size besar 0,29885. Standar deviasi untuk Size adalah 0,01811dibawah dari mean nya 0,29885. Dengan demikian dapat dikatakan tingkat variasi data dari 
Size terbilang kecil atau homogen artinya sebaran data penelitian baik.

Rasio Leverage terendah (minimum) sebesar 38,5252 yaitu pada PT Smartfren Telecom Tbk (FREN) pada tahun 2010 dan yang tertinggi (maksimum) sebesar 4,52656 yaitu pada PT Bakrie Telecom Tbk (BTEL) pada tahun 2012, kemudian rata-rata Leverage besarnya 0,17845. Sedangkan standar deviasi untuk Leverage adalah 7,17671 diatas dari meannya 4,52656. Dengan demikian dapat dikatakan tingkat variasi data dari rasio Leverage besar atau heterogen atau data pada Leverage relatif baik.

Rasio Growth terendah (minimum) sebesar 0,00776 pada PT Bakrie Telecom Tbk (BTEL) pada tahun 2016 dan yang tertingi (maksimum) sebesar 0,01535 yaitu pada PT Smartfren Telecom Tbk (FREN) pada tahun 2011, rata-rata Growth yaitu sebesar 0,00065 Sedangkan standar deviasi growth adalah 0,0036 diatas dari mean nya 0,00065. Dengan demikian dapat dikatakan tingkat variasi data dari rasio Growth besar atau heterogen atau data pada growth relatif baik.

\section{Uji Asumsi Klasik}

Uji Autokorelasi

Tabel 2. Hasil Uji Autokorelasi dengan Durbin-Watson

\begin{tabular}{|c|c|c|c|c|c|}
\hline \multicolumn{6}{|c|}{ Model Summary } \\
\hline Model & $\mathrm{R}$ & R Square & $\begin{array}{c}\text { Adjusted R } \\
\text { Square }\end{array}$ & $\begin{array}{c}\text { Std. Error of the } \\
\text { Estimate }\end{array}$ & Durbin-W atson \\
\hline 1 &, $956^{\mathrm{a}}$ &, 913 &, 902 & 1,128271 & 1,518 \\
\hline
\end{tabular}

Dalam Autokorelasi Test diperoleh nilai DurbinWatson sebesar 1,518 akan dibandingkan dengan nilai tabel Durbin-Watson yaitu nilai du=1,7259, dl=1,2221. Karena nilai Durbin-Watson hitung terletak

\section{Uji Normalitas}

Untuk mendeteksi normalitas data dapat diuji dengan dua cara yaitu: diantara batas $\mathrm{dl} \leq \mathrm{d} \leq$ du yaitu $1,2221<1,518<1,7259$ maka kesimpulan : tidak dapat disimpulkan atau tidak ada keputusan.

a. Kolmogorov-Sminov(K-S) dilakukan dengan tingkat signifikansi sebesar 0,05:

Tabel 3. Hasil Uji Normalitas

One-Sample Kolmogorov-Smirnov Test

\begin{tabular}{llr}
\hline & & Unstandardized Residual \\
\hline $\mathrm{N}$ & & 35 \\
Normal Parameters & Mean & .0000000 \\
Most Extreme Differences & Std. Deviation & 1.05983958 \\
& Absolute & .096 \\
Test Statistic & Positive & .096 \\
Asymp. Sig. (2-tailed) & & .096 \\
a. Test distribution is Normal. & .096 \\
b. Calculated from data. & $.200^{\text {c,d }}$ \\
C. Lilliefors Significance Correction. & \\
d. This is a lower bound of the true significance. &
\end{tabular}

Dari output diatas pada terlihat bahwa nilai signifikansi sebesar 0,2 lebih dari 0,05 maka dapat disimpulkan bahwa data dalam penelitian ini berdistribusi normal 
b. Analisis Grafik

Dari grafik terlihat bahwa keberadaan titik-titik berhimpitan dengan garis artinya data terdistribusi normal.

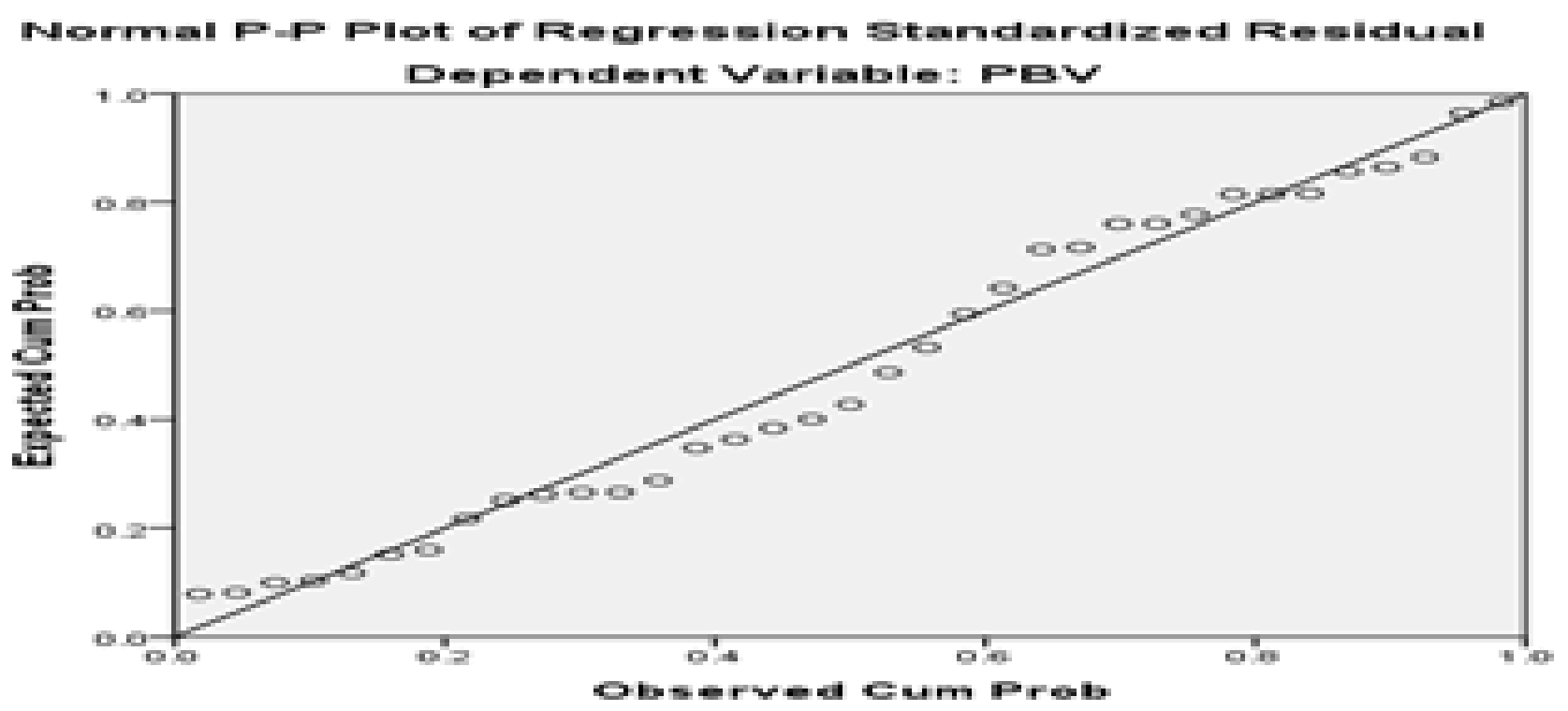

Gambar 2. Normal P-P Plot Regresion Standardized Residual

\section{Uji Heteroskedastisitas}

Untuk mendeteksi dapat dilakukan dengan: a. Analisis Grafik menggunakan metode Scatter plot, terlihat titik-titik menyebar secara acak serta tersebar baik diatas maupun dibawah angka 0 pada sumbu Y, kesimpulan tidak terdapat gejala heteroskedastisitas pada model regresi yang digunakan.

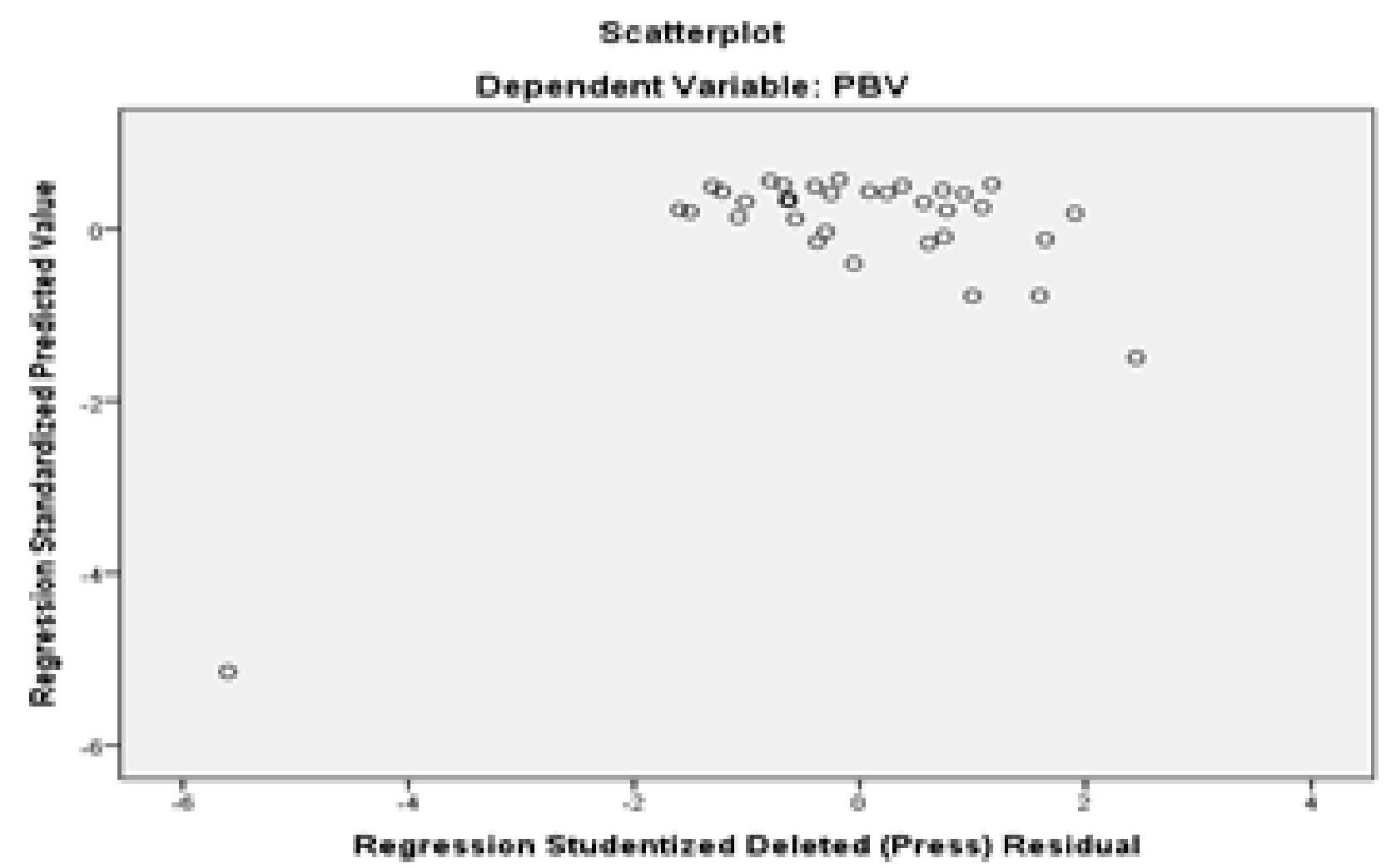

Gambar 3. Uji Heteroskedastisitas Dengan Metode Scatter Plot.

b. Uji Glejser dengan significance level (á) adalah 5\% menunjukkan nilai signifikan Z'Score dan Growth lebih lebih besar dari 0,05 maka disimpulkan model regresi bebas dari gangguan heterokedasitas. 
Tabel 4. Hasil Uji Heterokedasitas Dengan Uji Glejser

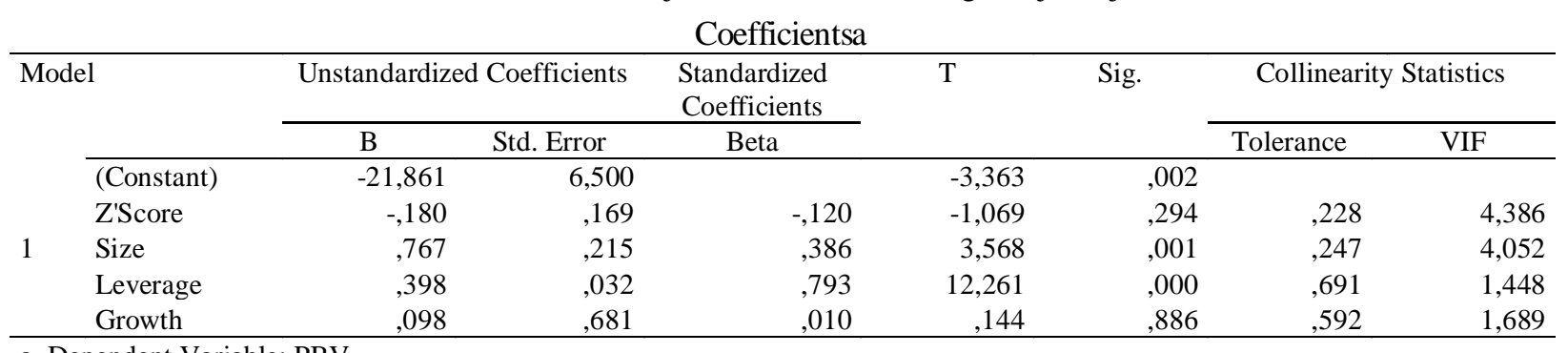

\section{Uji Multikolinieritas}

Tabel 5. Hasil Uji Multikolinieritas

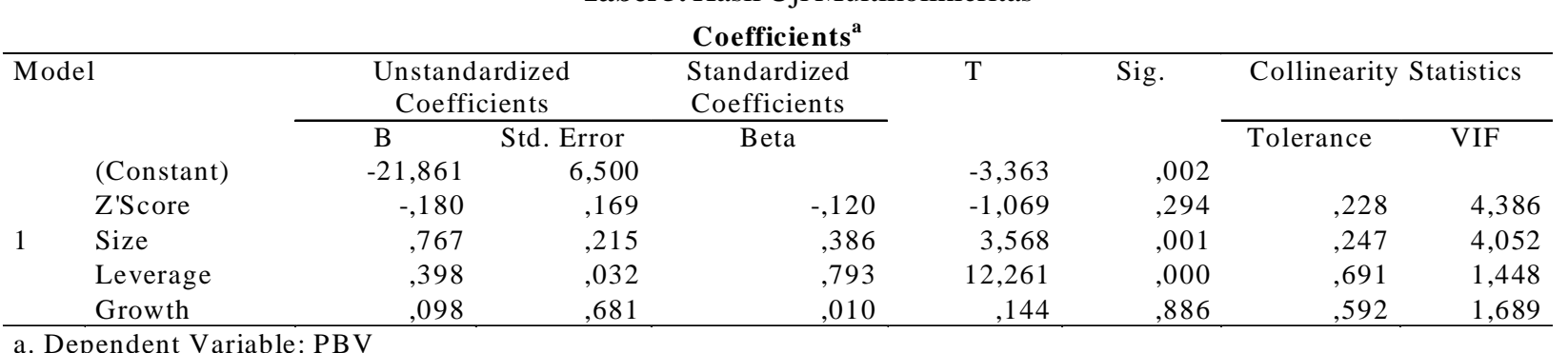

Dari table 5 diketahui bahwa nilai Tolerance dari variabel Z'Score sebesar 0,228; Size sebesar 0,247; Leverage sebesar 0,691, Growth sebesar 0,592 yang lebih dari 0,1 berarti model regresi bebas dari multikolinearitas. Nilai VIP keempat variabel independen kurang dari 10 dengan nilai berturut-turut

Uji Individual atau parsial (Uji t)

Pengujian Hipotesis statistic untuk uji-t dalam variabel independen Z'Score menunjukkan 4,386; Size menunjukkan 4,052; Leverage menunjukkan 1,448 serta Growth menunjukkan 1,689. Dapat disimpulkan bahwa tidak terjadi masalah multikolonearitas pada model regresi atau tidak terjadi korelasi antar variabel independen.

penelitian ini adalah sebagai berikut:

Tabel 6. Hasil Uji Signifikansi t Coefficients $^{\mathrm{a}}$

\begin{tabular}{|c|c|c|c|c|c|c|c|c|}
\hline & \multirow{3}{*}{ Model } & Unstandardiz & Coefficients & Standardized & $\mathrm{T}$ & Sio & \multirow{2}{*}{\multicolumn{2}{|c|}{ Collinearity Statistics }} \\
\hline & & & & Coefficients & & & & \\
\hline & & B & Std. Error & Beta & & & Tolerance & VIF \\
\hline \multirow{5}{*}{1} & (Constant) & $-21,861$ & 6,500 & & $-3,363$ & ,002 & & \\
\hline & Z'Score &,- 180 & , 169 &,- 120 & $-1,069$ & 294 & ,228 & 4,386 \\
\hline & Size & ,767 & ,215 & ,386 & 3,568 & ,001 & ,247 & 4,052 \\
\hline & Leverage & ,398 & 032 & ,793 & 12,261 & , 000 & ,691 & 1,448 \\
\hline & Growth & ,098 & ,681 & 010 & ,144 & ,886 & ,592 & 1,689 \\
\hline
\end{tabular}

a. Dependent Variable: PBV

Uji Hipotesa Pengaruh Z'Score Terhadap Nilai Perusahaan (PBV).

Dari hasil uji t yang telah dilakukan, hipotesa pertama menyatakan bahwa Tingkat Kebangkrutan Model Springate berpengaruh positif signifikan terhadap nilai perusahaan. Berdasarkan tabel 6 nilai t menunjukkan angka -1,069 dengan nilai signifikansi sebesar 0,294 > 0,05 maka $\mathrm{H}_{1}$ ditolak. Hal ini menunjukkan bahwa variabel Z-Score tidak memiliki pengaruh yang signifikan terhadap variabel PBV pada perusahaan telekomunikasi yang terdaftar di
BEI. Nilai beta -0,180 menunjukan arah yang negative. Artinya bahwa Z'Score mengalami kenaikan maupun penurunan tidak akan berpengaruh terhadap nilai perusahaaan. Hal ini tidak didukung penelitian dari Effendi, Azhar, Iwan Shidarta (2016), Ailando (2011) menyatakan bahwa Financial Distress berpengaruh positif terhadap nilai perusahaan. Hal ini karena naik turunnya harga saham berhubungan langsung dengan peningkatan dan penurunan nilai perusahaan sehingga mengurangi menambah kemakmuran pemilik saham. 


\section{b. Uji Hipotesa Pengaruh Size Terhadap Nilai Perusahaan.}

Dari hasil uji t yang telah dilakukan, hipotesa kedua menyatakan Size Firm berpengaruh positif signifikan terhadap nilai perusahaan. Berdasarkan table 6 nilai t menunjukkan angka 3,568 dengan nilai signifikansi sebesar 0,001 <0,05 dapat disimpulkan bahwa variabel Size mempunyai pengaruh signifikan terhadap nilai perusahaan, sehingga $\mathrm{H}_{2}$ diterima. Hal ini sesuai dengan hasil penelitian Maryam (2014), Prasetyorini (2013), I G Bagus Angga Pratama dan I Gusti Bagus Wiksuana (2016), Gede Rudangga dan Gede Merta Sudiarta (2016), Andyni Yulfanis Aulia Masrifa (2016) yang menyatakan bahwa ukuran perusahaan berpengaruh positif signifikan terhadap nilai perusahaan. Nilai Beta 0,767 menunjukkan arah yang positif artinya jika Size pada perusahaan telekomunikasi yang terdaftar di BEI meningkat, maka PBV (nilai perusahaan) akan meningkat pula, dan sebaliknya jika semakin kecil ukuran perusahaan maka semakin kecil pula nilai perusahaan. Hasil penelitian ini menunjukkan bahwa ukuran perusahaan yang besar bisa menjamin nilai perusahaannya tinggi, karena perusahaaan besar mungkin berani melakukan investasi baru terkait dengan ekspansi, sebelum kewajiban - kewajibannya (hutang) sudah terlunasi.

\section{c. Uji Hipotesa Pengaruh Leverage Terhadap Nilai Perusahaan.}

Dari hasil uji t yang telah dilakukan, hipotesa ketiga menyatakan Leverage berpengaruh positif signifikan terhadap nilai perusahaan. Berdasarkan table 6 nilai t menunjukkan angka 12,261 dengan nilai signifikansi sebesar 0,000 $<0,05$ dapat disimpulkan bahwa variabel Leverage mempunyai pengaruh terhadap nilai perusahaan, sehingga H3 diterima, dan nilai Beta 0,398 menunjukkan arah yang positif. Hal ini sesuai dengan hasil penelitian Hermuningsih (2013), Uguanyi (2012), I Gusti Bagus Angga Pratama dan I Gusti Bagus Wiksuana (2016), I Gusti Gede Rudangga dan Gede Merta Sudiarta (2016) bahwa Leverage secara parsial berpengaruh positif signifikan terhadap Nilai Perusahaan (PBV). Artinya bahwa semakin tinggi Leverage, akan semakin tinggi pula Nilai Perusahaan yang diperoleh karena leverage dapat mengurangi beban pajak sehingga pembagian return saham yang diperoleh investor lebih tinggi, dengan penggunaan leverage dapat meningkatkan kegiatan operasional karena dengan hutang akan memperoleh modal yang cukup untuk dapat bertahan dan berkembang sehingga mampu mmeberikan return saham yang tinggi pada investor.

\section{d. Uji Hipotesa Pengaruh Growth Terhadap Nilai Perusahaan.}

Dari hasil uji t yang telah dilakukan, hipotesa keempat menyatakan Growth berpengaruh positif signifikan terhadap nilai perusahaan. Berdasarkan table 6 nilai t menunjukkan angka 0,144 bahwa signifikansi sebesar 0,886 >0,05 dapat disimpulkan bahwa variabel growth secara parsial tidak berpengaruh terhadap PBV perusahaan telekomunikasi periode 2010-2016, sehingga H4 ditolak dan nilai Beta 0.098. Hal ini sesuai dengan hasil penelitian dari Verawati Hansen dan Juniarti (2014), serta Andyni Yulfanis Aulia Masrifa (2016) dan menyatakan bahwa sales growth memiliki pengaruh yang positif dan tidak signifikan terhadap nilai perusahaan. Artinya bahwa sales growth mengalami kenaikan maupun penurunan tidak akan berpengaruh terhadap nilai perusahaaan.

\section{Uji Menyeluruh atau Simultan (Uji F)}

Tabel 7. Hasil Uji Signifikansi F

\begin{tabular}{|c|c|c|c|c|c|c|}
\hline \multicolumn{7}{|c|}{ ANOVA ${ }^{a}$} \\
\hline \multirow{4}{*}{$\begin{array}{l}\mathrm{M} \\
1\end{array}$} & & $\begin{array}{r}\text { Sum of } \\
\text { Squares }\end{array}$ & $\mathrm{Df}$ & Mean Square & $\mathrm{F}$ & Sig. \\
\hline & Regression & 402.037 & 4 & 100.509 & 78.953 & $.000^{\mathrm{b}}$ \\
\hline & Residual & 38.191 & 30 & 1.273 & & \\
\hline & Total & 440.228 & 34 & & & \\
\hline
\end{tabular}

a. D ependent V ariable: PB V

b. Predictors: (Constant), Growth, Size, Leverage, Z'S core

Untuk melakukan Uji F terdapat dua cara: a) Pada $\mathrm{F}$ hitung $>\mathrm{F}$ tabel =78,953 > 2,69 maka H5 diterima, artinya Variabel Z'Score, Size, Leverage dan Growth secara simultan berpengaruh terhadap Nilai Perusahaan; b) Pada tabel uji F maka nilai sig. yaitu 0,000< 0,05 maka artinya secara bersamaan (simultan) variabel $Z$ score, size, leverage dan sales growth berpengaruh secara signifikan terhadap nilai perusahaantelekomunikasi. 


\section{Uji Koefisien Determinasi (Uji As R-Square)}

\begin{tabular}{ccccc} 
Model Su m mary & \multicolumn{4}{c}{ Tabel 8. Nilai Koefisien Determinasi (R Square) } \\
\hline M odel & $\mathrm{R}$ & R Square & $\begin{array}{c}\text { Adjusted R } \\
\text { Square }\end{array}$ & $\begin{array}{c}\text { Std. Error of the } \\
\text { Estim ate }\end{array}$ \\
\hline 1 & $.956^{\mathrm{a}}$ & .913 & .902 & 1.12829 \\
\hline
\end{tabular}

a. Predictors: (Constant), Growth, Size, Leverage, Z'Score

b. Dependent Variable: PBV

Dari hasil Uji R2adalah 90,2\% Nilai Perusahaan dipengaruhi oleh variabel Z’Score, Size, Leverage,
Growth dan sisanya 9,8\% dipengaruhi oleh variabel lain diluar variabel yang diteliti.

\section{Analisis Regresi Liniear Berganda}

\begin{tabular}{|c|c|c|c|c|c|c|c|c|}
\hline & & & $\begin{array}{r}\text { Tabe } \\
\text { Coeffic }\end{array}$ & $\begin{array}{l}\text { 9. Hasil Analisis } \\
\text { ents }^{\mathrm{a}}\end{array}$ & & & & \\
\hline & & Unstand & ardized & Standardized & $\mathrm{T}$ & Sig. & Collinearity & atistics \\
\hline & & B & Std. Error & Beta & & & Tolerance & VIF \\
\hline & (Constant) & $-21,861$ & 6,500 & & $-3,363$ & ,002 & & \\
\hline & Z'Score &,- 180 & 169, &,- 120 & $-1,069$ & 294 & ,228 & 4,386 \\
\hline 1 & Size & ,767 & ,215 & ,386 & 3,568 & ,001 & ,247 & 4,052 \\
\hline & Leverage & ,398 & ,032 & ,793 & 12,261 & ,000 & ,691 & 1,448 \\
\hline & Growth & ,098 & 681 & ,010 & 144 & ,886 &, 592 & 1,689 \\
\hline
\end{tabular}

a. Dependent Variable: PBV

$\mathrm{Y}=-21,860-0,18 Z$ 'Score + 0,767 Size + 0,398 Leverage + 0,098 Growth + e , artinya: a) Nilai konstanta bernilai negatif sebesar $-21,861$, menunjukkan bahwa apabila keseluruhan variabelvariabel independen (Z'Score, Size, Leverage, Growth) konstan, maka PBV sebesar-21,861; b) Z'Score mempunyai koefisien regresi sebesar -0,18, artinya apabila nilai Z’Score mengalami kenaikan sebesar satu satuan maka Nilai Perusahaan akan mengalami penurunan sebesar 0,18 dengan asumsi nilai variabel lain tetap; c) Size mempunyai koefisien regresi sebesar 0,767, artinya apabila nilai Size mengalami kenaikan sebesar satu satuan, maka Nilai Perusahaan akan mengalami kenaikan sebesar 0,767 dengan asumsi nilai variabel lain tetap; d) Leverage mempunyai koefisien regresi sebesar 0,398, artinya apabila nilai Leverage mengalami kenaikan sebesar satu satuan, maka Nilai Perusahaan akan mengalami kenaikkan sebesar 0,398 dengan asumsi nilai variabel lain tetap; e). Growth mempunyai koefisien regresi sebesar 0,098, artinya apabila nilai Growth mengalami kenaikan sebesar satu satuan, maka Nilai Perusahaan akan mengalami kenaikkan sebesar0,098 dengan asumsi nilai variabel lain tetap.

\section{Pembahasan}

Pembahasan penelitian menyangkut pada tujuan dari penelitian yaitu: 1) Z'Score secara parsial dengan variabel PBV tidak mempunyai pengaruh yang signifikan yang ditunjukkan oleh t hitung sebesar -1,068 dan nilai t tabel sebesar 1,697, dan nilai probabilitas (signifikan) sebesar 0,294 yang lebih besar dari 0.05, maka H1 ditolak. Jadi dapat disimpulkan bahwa Z'Score secara parsial tidak berpengaruh signifikan terhadap Price Book Value. Hal ini berarti bahwa potensi kebangkrutan dengan pendekatan Springate tidak mempengaruhi dalam menentukan pergerakan harga saham telekomunikasi di Bursa Efek Indonesia; 2) Size secara parsial berpengaruh signifikan terhadap variabel PBV yang ditunjukkan oleh thitung sebesar 3,568 dan nilai t tabel sebesar 1,697 dan nilai probabilitas (signifikan) sebesar 0,001dimana lebih kecil dari 0.05 maka H2 diterima. Jadi dapat disimpulkan bahwa Size secara parsial berpengaruh postif signifikan terhadap Price Book Value; 3. Leverage secara parsial berpengaruh signifikan terhadap variabel PBV yang ditunjukkan oleh nilai t hitung sebesar 12,260 dan nilai t tabel sebesar 1,697 
dan nilai probabilitas (signifikan) sebesar 0,000 dimana lebih kecil dari 0.05 maka H3 diterima. Jadi dapat disimpulkan bahwa Leverage berpengaruh positif signifikan terhadap PBV; 4) Growth secara parsial tidak berpengaruh signifikan terhadap variabel PBV yang ditunjukkan oleh nilai t hitung sebesar 0,144 dan nilai t tabel sebesar 1,697dan nilai probabilitas (signifikan) sebesar 0,886 dimana lebih besar dari 0.05 maka $\mathrm{H} 4$ ditolak, disimpulkan bahwa Growth dengan variabel PBV tidak memiliki pengaruh yang signifikan; 5) Dengan membandingkan Sig. pada tabel ANOVA dengan taraf nyatanya (alfa 0,05\%). Jika Sig. >0,05 maka model ditolak, namun Sig $<0,05$ maka model diterima. Pada tabel uji F diatas yaitu 0,000 maka nilai sig. $<0,05$ maka dapat disimpulkan model dapat diterima artinya secara bersamaan (simultan) variabel $Z$ score, size, leverage dan growth berpengaruh secara signifikan terhadap nilai perusahaanTelekomunikasi di Bursa Efek Indonesia.

\section{KESIMPULAN DAN SARAN}

\section{Kesimpulan}

Berdasarkan hasil analisis data dan pembahasan, maka dapat tarik kesimpulan: 1) Z'Score secara parsial tidak mempunyai pengaruh yang signifikan dengan Price Book Value; 2) Size secara parsial berpengaruh positif signifikan dengan Price Book Value; 3) Leverage secara parsial berpengaruh positif signifikan dengan Price Book Value; 4)

Sales Growth secara parsial tidak berpengaruh signifikan dengan Price Book Value; 5) Z score, Size, Leverage dan Sales growth secara bersamaan (simultan) berpengaruh secara signifikan terhadap Price Book Value

\section{Saran}

Penulis mencoba memberikan beberapa saran sebagai berikut: 1) Bagi Investor : Metode Z"Score dapat dijadikan alat untuk melakukan keputusan investasi. Dimana Perusahaan dengan nilai Z"Score yang rendah dan tidak menunjukkan perbaikan kinerja sebaiknya dihindari untuk menginvestasikan dananya kedalam sahamnya pada perusahaan tersebut. Dengan melihat perkembangan Size perusahaan yang meningkat dan leverage perusahaan serta peningkatan growth dapat dijadikan pertimbangan untuk melakukan keputusan invetasi; 2) Bagi Pihak Perusahaan: Metode Z"Score dapat dijadikan sebagai alat evaluasi perusahaan, sehingga manajemen perusahaan dapat selalu meningkat kinerja agar terhindar dari perusahaan yang berpotensi bangkrut. Dengan kinerja yang baik maka banyak investor akan menanamkan modalnya ke perusahaan; 3) Bagi Peneliti Selanjutnya: Disarankan untuk menambah jumlah sampel dan jumlah tahun penelitian sehingga mampu memberikan temuan Metode Z'Score dapat mempengaruhi Price Book Value suatu perusahaan.

\section{DAFTAR PUSTAKA}

Ailando Siregar, (2008), "Pengaruh Potensi Kebangkrutan Altman Terhadap Pergerakan Harga Saham Perusahaan Manufaktur Terbuka di BEI, Thesis Ilmu Manajemen Universitas Sumatera Utara, Medan

Andyni Yulfanis Aulia Masrifa, (2016), Karakteristik Perusahaan Terhadap Nilai Perusahaan, Dengan Dividend Payout Rasio Sebagai Variabel Intervening, Jurnal Advance, Vol 3 No 1 (2016)

Adrian, Andromeda, dan Khoiruddin, Moh ,(2014),Pengaruh Analisis Kebangkrutan Model Altman Terhadap Harga Saham Perusahaan Manufaktur, Management Analysis Journal, Vol 3 No 1, 2014, Juni 11, 2014

Baridwan, Zaki, (2008), Sistem Akuntansi Penyusunan Prosedur dan Metode, Edisi Kelima, Yogjakarta : BPPE

Bursa Efek Indonesia.(2016). Laporan Tahunan.http:// www.idx.co.id. Diakses 20Desember 2017.

Darsono, Ashari, (2005), Pedoman Praktis Memahami Laporan Keuangan, Jakarta : Salemba Empat

Diakomihalis, Mihail. (2012),The Accuracy of Altman's Model in Predicting Hotel Bankcrutcy. Dalam International Journal of Accounting and Financial Reporting Vol. 2 No.2

Effendi, Azhar, Iwan Shidarta (2016), Analisa Pengaruh Rasio Keuangan Model Springate Terhadap Harga Saham Pada Perusahaan Publik Sektor Telekomunikasi, Jurnal Ekonomi, Bisnis \& Entrepreneurship, Vol 10 No 1 (April 2016), ISSN 24432121

Endri. (2009). Prediksi Kebangkrutan Bank Untuk Menghadapi dan Mengelola Perubahan Lngkungan Bisnis : Analisis Model Altman Z-Score, Jurnal Ekonomi dan Bisnis, ISSN. 1078-9017.

Fahmi, Irham, (2014), Analisisis Laporan Keuangan, CV. Bandung : Alfabeta

Fahmi, Irham, (2013), Manajemen Kinerja, Cetakan Ketiga, Bandung, Alfabeta

Fahmi, Irham, (2013), Analisis Laporan Keuangan, CV. Bandung, Alfabeta

Fatmawati, Hilda Nia, (2012), Analisis Penilaian Financial Distress Menggunakan Springate Model Sebagai Prediktor Delisting. Dalam Jurnal Keuangan dan Perbankan Vol.16 No 1 Hal 56-65

Ferbianasari, Hilda Nia. (2012).Analisis Penilaian Financial Distress Menggunakan Model Altman (Z-Score) pada Perusahaan Kosmetik Yang Tercatat di Bursa Efek Indonesia, Jawa Timur : Universitas Negeri Surabaya 
I Gusti Bagus Angga Pratama, I Gusti Bagus Wiksuana (2016), Pengaruh Ukuran Perusahaan dan Leverage Terhadap Nilai Perusahaan Dengan Profitabilitas Sebagai Variabel Mediasi, E-Jurnal Manajemen Unud, Vol. 5, No. 2, 2016: 1338-1367

I Gusti Ngurah Gede Rudangga dan Gede Merta Sudiarta (2016), "Pengaruh Ukuran Perusahaan, Leverage, Dan Profitabilitas Terhadap Nilai Perusahaan, E Jurnal Manajemen Unud, Vol 5 No 7, 2016 : 4394-4422, ISSN :2302-8912

I Nyoman Agus Suwardika dan I Ketut Mustanda (2017), Pengaruh Leverage, Ukuran Perusahaan, Pertumbuhan Perusahaan, Dan Profitabilitas Terhadap Nilai Perusahaan Pada Perusahaan Properti, E-Jurnal Manajemen Unud, Vol 6, No 3, 2017 : 12481277, ISSN : 2302-8912

Ghazali, Imam. Analisis Multivariate Lanjutan dengan Program SPSS, Badan Penerbit Universitas Diponegoro, Semarang, 2006

Ghodrati, H., \& Moghaddam, A. (2012), A Study of the Accuracy of Backruptcy Prediction Models : Altman, Shirata, Ohlson, Zmijewsky, CA Score, Fulmer, Springate, Farajzadeh Genetic, and McKee genetic Models for the Companies of the Stock Exchange of Tehran, American Journal of Scientific Research

Ginanjar Indra Kusuma, Suhadak, Zainal Arifin, “Analisis Pengaruh Profitabilitas (Profitability) dan Tingkat Pertumbuhan (Growth) Terhadap Struktur Modal dan Nilai Perusahaan (Studi Pada Perusahaan Real Estate dan Property Yang Terdaftar di Bursa Efek Indonesia Periode 2007-2011)"

Hazlina Safitri Pengaruh Size, Growth, Dengan Kebijakan Deviden Sebagai Variabel Moderating Terhadap Nilai Perusahaan

Hermuningsih, (2013), Profitability, Growth Opportunity, Capital Structure And Firm Value, Bulletin of Monetary Economic And Banking, Vol 16, No 2, (October 2013)

Hidayati, Eva Eko (2010), Analisis Pengaruh DER, DPR, ROE, Dan Size Terhadap PBV Perusahaan Manufaktur Yang Listing Di BEI Periode 2005-2007, Thesis Program Studi Magister Management, Universitas Diponegoro, Semarang

Indri (2012), Kekuatan Rasio Keuangan Dalam Memprediksi Kondisi Financial Distress Perusahaan Manufaktur Yang Terdaftar di BEI, Jurnal Dinamika Akuntansi Terhadap Nilai Perusahaan, Jurnal Ilmu Manajemen, Vol 1 Nomor 1, Januari 2013

Luciana, S.A. (2004), Analisis Faktor-Faktor Yang Mempengaruhi Kondisi Financial Distress Suatu Perusahaan Yang Terdaftar di Bursa Efek Jakarta. Jurnal Riset Akuntansi Indonesia (JRAI), Vol 7 No.1, 2004
Luciana, S.A.dan Kristijadi. (2003), Analisis Rasio Keuangan Untuk Memprediksi Kondisi Financial Distress Perusahaan Manufaktur Yang Terdaftar di Bursa Efek Jakarta. Jurnal Akuntansi dan Auditing Indonesia (JAAI), Vol 7 No.2, ISSN, 1410-2420, 2003

Maryam, Sitti. (2014). Analisis Pengaruh Firm Size, Growth, Leverage, dan Profitabilitas terhadap Nilai Perusahaan (Studi pada Perusahaan Manufaktur yang terdaftar di Bursa Efek Indonesia). Skripsi S1 Universitas Hasanuddin, Makassar.

Prasetyorini, (2013), Pengaruh Ukuran Perusahaan, Leverage, Price Earning Ratio Dan Profitabilitas Peter dan Yoseph, (2011), Analisis Kebangkrutan Dengan Metode Z-Score Altman, Springate Dan Zmijewski Pada PT Infofood Sukses Makmur Tbk

Periode 2005-2009, Journal Ilmiah Akuntansi, Nomor 4 Tahun Ke-2 Januari-April 2011

Putu Mikhy Novari dan Putu Vivi Lestari, (2016), Pengaruh Ukuran Perusahaan, Leverage dan Profitabilitas Terhadap Nilai Perusahaan Pada Sektor Properti dan Real Estate, E-Jurnal Manajemen Unud, Vol. 5 No 9, 2016: 5671-5694, ISSN : 2302-8912

Raissa Karima, Loman Mariana Ing Malelak, (2015), Determinan Terhadap Prediksi Fianacial Distress Pada Perusahaan Manufaktur Di Bursa Efek Indonesia,Journal of Research in Economic and Management, Volume 15, No. 2, Juli - Desember (Semester II) 2015, Halaman 371-381

Saputra, Fadly, (2016), Analisis Pengaruh Profitabilitas, Keputusan Investasi, Leverage, Ukuran Perusahaan Terhadap Nilai Perusahaan (Studi Pada Perusahaan Manufaktur Yang Terdaftar di Bursa Efek Indonesia 2012-2014), Jurnal UMY Research Repository,

Sundjaya, Ridwan S. dan Enge Barlian, (2002), Manajemen Keuangan Dua, Edisi Keempat, Literata Lintas Media, Jakarta

Sarwanih, (2007), Perbandingan Antara Model Altman dan Model Shumway Terhadap Prediksi Kondisi Financial Distres Perusahaan Manufaktur, Skripsi, UIN Syarif Hidayatullah Jakarta.

Sriwandany (2006). Pengaruh Pertumbuhan Perusahaan terhadap KebijakanStruktural Modal dan Dampaknya terhadap Perubahan Harga Sahampada Perusahaan Manufaktur Tbk. Tesis, Universitas Sumatera Utara

Steven dkk (2011), Effects of Financial Distress Condition on the Company Performance : A Malaysia Perspective"Review of Economic \& Finance, Malaysia

Tanjung, Ninik Mardiana, (2011), Analisis Potensi Kebangkrutan dan Hubungannya dengan Return Saham Pada Perusahaan Perbankan Yang Terdaftar Di Bursa Efek Indonesia Peridoe 2007-2010, Penerbit Program Studi Magister Manajemen Sekolah Pascasarjana Universitas Katolik Indonesia Atmajaya. 
Verawati Hansen dan Juniarti (2014), Pengaruh Family Control, Size, Sales Growth, dan Leverage Terhadap Profitabilitas dan Nilai Perusahaan Pada Sektor Perdagangan Jasa dan Investasi, Business Accounting Review, Vol 2 No 1, 2014, 